ISSN 1392-3196 / e-ISSN 2335-8947

Zemdirbyste-Agriculture, vol. 104, No. 2 (2017), p. 165-172

DOI 10.13080/z-a.2017.104.021

\title{
Water-soluble carbohydrates accumulation in peduncle of wheat and its relationship to morpho-anatomical and productive traits
}

\author{
Aleksandra ŠEŠLIJA ${ }^{1}$, Biljana VUCELIĆ-RADOVIĆ ${ }^{1}$, Sladjana STANOJEVIĆ ${ }^{1}$, \\ Jasna SAVIĆ ${ }^{1}$, Dragana RANČIĆ ${ }^{1}$, Ilinka PEĆINAR ${ }^{1}$, Vesna KANDIĆ ${ }^{2}$, Dejan DODIG ${ }^{2}$ \\ ${ }^{1}$ University of Belgrade \\ 6 Nemanjina str., 11080 Zemun-Belgrade, Serbia \\ ${ }^{2}$ Maize Research Institute Zemun Polje \\ 1 Slobodana Bajića str., 11185 Zemun-Belgrade, Serbia \\ E-mail: dejanza@yahoo.com
}

\begin{abstract}
Water-soluble carbohydrates (WSC) accumulating in internodes of the wheat stem can be a consequential contributor to grain filling, especially under stress conditions. In this study the WSC content and the WSC specific content (WSCSC) per unit of length were determined in the uppermost internode (peduncle) of the main stem at 10 days after anthesis across 44 wheat genotypes in two-year field trials. The defoliation was done at 10 days after anthesis by cutting off all leaf blades and defoliated plants were grown along with the intact control plants. Among 16 morphological, anatomical and developmental traits, the area of pith intercellular of peduncle, chlorophyll content in flag leaf and the flag leaf area appeared to be most important for WSC accumulation in peduncle. High WSCSC genotypes tended to have higher grain weight per spike than low WSCSC genotypes both in defoliated and control plants.
\end{abstract}

Key words: defoliation, fructan, genotypes, grain weight, Triticum aestivum.

\section{Introduction}

Wheat yield in many rain-fed agricultural systems worldwide has been affected by the process of global climate change, manifested by the annual precipitation decrease and the increase in mean annual temperatures during the reproductive growth stage. Extreme climate events (such as drought and/or heat stress) during the reproductive growth stage of wheat can lead to significant reduction in yield and quality (Chaves, Davies, 2010). Therefore, improving tolerance to stress conditions during this stage is necessary to contribute to sustained grain yield of wheat in a future drier and warmer climate. Several studies suggested that watersoluble carbohydrates reserves in stems were the best strategy to improve yield under water limited conditions during grain filling (Ehdaie et al., 2008; Dreccer et al., 2009; Saint Pierre et al., 2010).

Plants provide the needed assimilates for grain growth from current photosynthesis and remobilisation of reserve carbohydrates from stem to grains (Nawaz et al., 2013). In wheat, stem internodes and flag leaf sheath are the main parts in which water-soluble carbohydrates (mostly in the form of fructans) are accumulated as reserves during vegetative and early reproductive growth (Scofield et al., 2009). Later, when the stage of rapid grain filling starts, carbohydrate reserves become mobile and partition to the developing grain (Ruuska et al., 2006) contributing $20-62 \%$ of final grain weight under normal conditions and 40-100\% under post-anthesis drought (Blum, 1998; Yang et al., 2007; Ehdaie et al., 2008). Since photosynthesis is one of the most sensitive processes affected by heat stress (Prasad et al., 2008), there are changes in the relative contributions of stem during the grain filling process.

The peduncle located at the first internode directly below the spike, accounts for a considerable proportion of the total stem length in wheat and is thus an important organ for carbohydrate storage (Saint Pierre et al., 2010). In drought conditions mobilization efficiency of stored carbohydrates in the peduncle was improved more than in lower internodes ( $33 \%$ vs 14\%) compared to non-stress conditions (Ehdaie et al., $2006 \mathrm{~b}$ ). The penducle has a diversity of other critical roles in crop productivity such

Please use the following format when citing the article:

Šešlija A., Vucelić-Radović B., Stanojević S., Savić J., Rančić D., Pećinar I., Kandić V., Dodig D. 2017. Water-soluble carbohydrates accumulation in peduncle of wheat and its relationship to morpho-anatomical and productive traits. ZemdirbysteAgriculture, 104 (2): 165-172 DOI 10.13080/z-a.2017.104.021 
as carbohydrate metabolism or in maintaining higher water potential than the flag leaf under drought stress or high temperatures (Kong et al., 2010). The morphology of peduncle has been related to grain yield and drought tolerance in wheat (Villegas et al., 2007; Li et al., 2011). On the other hand, relationships between peduncle anatomy and grain yield, have been less studied.

In our study we evaluated the ability of different wheat genotypes to accumulate reserve carbohydrates in peduncle of plants grown under normal and stress conditions during grainfilling simulated byleafdefoliation. Our goals were: (i) to identify among a number of morphological, anatomical and physiological traits those that contributed the most to water-soluble carbohydrate accumulation in peduncle and (ii) to determine whether there were differences between contrasting genotype groups for water-soluble carbohydrate specific content in their characteristics, including productive traits, under normal and stress conditions.

\section{Materials and methods}

Plant material and growing conditions. A set of 44 genotypes of winter and facultative wheat (Triticum aestivum L.) including standard genotypes (consisting of 17 entries) and $\mathrm{F}_{4.5}$ families (consisting of 27 entries) were used in this study. Standard genotypes represented cultivars or advanced breeding lines used as standards for grain yield and other agronomic traits. Serbian Variety Commission uses two of these genotypes, 'Pobeda' and 'Renesansa', as standards in the official trials. $F_{4: 5}$ families represented selected crosses that were made between selected genotypes on the basis of data on SSR alleles for markers associated with the three key yield components (spikes/plant, grains/spike and thousand grains per weight) and traditional phenotypic criteria (grain yield, plant biomass, harvest index and drought tolerance). Progenies of crosses were taken through to $\mathrm{F}_{4}$ (2010-2011) and $\mathrm{F}_{5}$ (2011-2012) generations. Only those lines that were phenotypically adapted on the basis of medium height, early/medium flowering date, large grains and good disease resistance were kept. Genotype names, origin, parentage and criteria for crosses are given elsewhere (Dodig et al., 2016).

This experiment was carried out in the north of Serbia (44.52' $\mathrm{N}$ and $20^{\circ} 19^{\prime} \mathrm{E}, 82 \mathrm{~m}$ a.s.l.) during two growing seasons (2010-2011 and 2011-2012). The site is characterised by a moderate continental climate. Winters are cold and summers are hot and dry. Investigated genotypes were planted in late October and harvested in late June the following year. Each plot consisted of ten $1-\mathrm{m}$-long rows, spaced at $20 \mathrm{~cm}$, with a seeding rate of 450 seeds $\mathrm{m}^{-2}$. To prevent the reduction of reserve accumulation and storage capacity in stems, plants were additionally irrigated by the end of stem elongation (during March, April and early May). The irrigated plots were watered manually when water in the top $75 \mathrm{~cm}$ of soil had declined to less than $50 \%$ of field capacity. The defoliation was done at 10 days after anthesis (DAA) (around the start of the rapid grain filling phase) by cutting off all leaf blades. Control plants were left intact. Standard cropping practices were applied to provide adequate nutrition and to keep plots free of pests, diseases and weeds. Summarized meteorological data for the winter wheat crop cycle in spring (March-June) is provided in Figure 1. Daily mean temperatures, number of days with maximum temperature over $30^{\circ} \mathrm{C}$ and precipitation were recorded from the nearest weather station of Republic Hydrometeorological Service of Serbia.

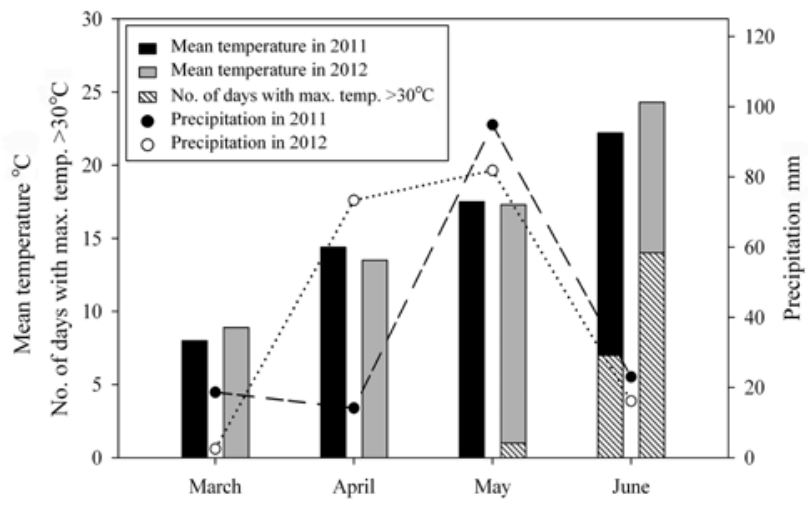

Figure 1. Meteorological data at the experimental site in 2011 and 2012

Measurements. Fifteen uniform wheat plants flowering on the same day from interior rows within each plot were labelled for sampling. Five labelled plants were sampled at 10 days after anthesis. Another ten plants (five per treatment) were sampled at physiological maturity. All observations and measurements were based on the main stem peduncle. Water-soluble carbohydrates (WSC) were measured at 10 days after anthesis. The size of a sample was determined by cutting it half way between the flag leaf ligula and the flag leaf node on its lower side and half way between the flag leaf ligula and the base of spike on its upper side. Both parts of peduncle lower unexposed (enclosed by flag leaf sheath) and upper exposed make up the samples for determination of WSC as described in Yang et al. (2007) with some modification. Briefly, samples were dried at $70^{\circ} \mathrm{C}$ until a constant dry weight. Then samples were cut into pieces $1 \sim 2 \mathrm{~mm}$ in length and $0.1-0.2 \mathrm{~g}$ of dry material for each sample with three replications was used for extraction. Samples were boiled in $40 \mathrm{ml} \mathrm{dd} \mathrm{H}_{2} \mathrm{O}$ for $40 \mathrm{~min}$, fractions were filtered and filtrates were transferred to volumetric flasks $(50 \mathrm{ml})$ and brought to $50 \mathrm{ml}$ by addition of $\mathrm{dd} \mathrm{H}_{2} \mathrm{O}$. The total amount of WSC was expressed as mg WSC $100 \mathrm{mg}^{-1}$ dry weight (DW) and was determined as fructose equivalents using the anthrone colorimetric assay. The WSC content of peduncle was divided by its length to calculate WSC specific content (WSCSC) (mg cm-1 WSC length). All samples and standards were determined as a mean value of three replicate measurements that differed by less than 5\%. Measurements of morphological, anatomical and productive traits used in this study for their effect on WSC-related traits were described in Dodig et al. (2016).

Statistical analysis. Data were processed by the two way analysis of variance (ANOVA) and the LSD test was used to determine the significance of differences between the genotypes using the statistical software SigmaPlot, version 11.0 (Jandel Scientific, Germany). The broad sense heritability ( $h 2$ ) was estimated from ANOVA table by calculating the variance components in according to Hallauer et al. (2010). To assess variable importance for WSC and WSCSC random forest (RF) method (Genuer et al., 2010) was accomplished within the computing environment $R$ ( $R$ Core Team, 2014). The genotypes were grouped as either high (10 highest) or low (10 lowest) in WSCSC according to the performance in each year, and their means were compared by the $t$-test. 


\section{Results}

The rainfall pattern in March-April (tillering and stem elongation) was rather different between the two years (Fig. 1), but the additional irrigation during that period ensured sufficient water supply for biomass accumulation. During anthesis and grain filling (MayJune) rainfall was lower, while temperatures were higher in 2012, particularly in June during grain filling. Number of days with maximum temperatures above $30^{\circ} \mathrm{C}$ for June in 2012 was two-fold higher than in 2011 (14 vs 7).

Considerable variation (over $30 \%$ ) was estimated for WSCSC in 2012, followed by WSCSC in 2011 and WSC in both years (between 20\% and 30\%) (Table 1). WSC ranged from 1.52 to $3.54 \mathrm{mg} 100 \mathrm{mg}^{-1}$ DW in 2011 and from 0.86 to $2.87 \mathrm{mg} 100 \mathrm{mg}^{-1} \mathrm{DW}$ in 2012. WSCSC ranged from 2.23 to $7.05 \mathrm{mg} \mathrm{cm}^{-1}$ in 2011 and from 1.02 to $6.49 \mathrm{mg} \mathrm{cm}^{-1}$ in 2012. According to the $t$-test $(P<0.001)$, there was significant difference in mean WSC (2.31 vs 1.91) and WSCSC (3.94 vs 3.03) between 2011 and 2012, respectively.

The ANOVA indicated that main effects of a genotype, year and their interaction on both biochemical traits were significant $(P<0.01)$ (Table 2). A genotype was the most influential factor for WSC and WSCSC (66\% and $63 \%$, respectively), while the genotype $\times$ year interaction was estimated by proportion of around $20 \%$ in the total sum of squares for both traits.

The RF method was used to define variable importance for WSC and its linear density (WSCSC). For this analysis we used 16 morphological, anatomical and developmental traits, all (except days to flowering) measured/sampled at 10 days after anthesis, just before defoliation. Variable importance according to RF method was presented in Table 3 .

To further examine any association between water-soluble carbohydrates accumulation in peduncle and other studied traits, means of two selected genotype groups were compared in both years: one with ten highest values of WSCSC (high) and another with ten lowest values of WSCSC (low) (Table 4).

We chose WSCSC instead of WSC for selection of genotypes with the intention of adjusting the genotypic differences in peduncle length. Nevertheless, WSC also significantly differed between high- and low-WSCSC groups. Finally, we examined differences between high- and low-WSCSC genotypes for peduncle relative contribution to grain weight and for the peduncle mobilisation efficiency (Fig. 2).

High-WSCSC genotypes had significantly higher contribution $(P<0.001)$ to grain weight/main spike (GWS) in control plants from peduncle than lowWSCSC genotypes (19.1\% vs 8.6\%, respectively). The similar one-fold higher contribution $(P<0.001)$ to GWS from peduncle in high-WSCSC genotypes than in lowWSCSC genotypes was estimated for defoliated plants
Table 1. Water-soluble carbohydrates (WSC) content and water-soluble carbohydrates specific content (WSCSC) at 10 days after anthesis in 2011 and 2012 and their coefficient of variation $(\mathrm{CV})$

\begin{tabular}{|c|c|c|c|c|c|}
\hline \multirow{2}{*}{ Genotype } & \multirow{2}{*}{ Group } & \multicolumn{2}{|c|}{2011} & \multicolumn{2}{|c|}{2012} \\
\hline & & $\mathrm{WSC}^{1}$ & $\mathrm{WSCSC}^{2}$ & WSC & WSCSC \\
\hline MRI 87/A & $\mathrm{S}$ & 2.96 & 4.36 & 2.02 & 3.21 \\
\hline MRI 87/B & $\mathrm{S}$ & 1.76 & 2.47 & 0.86 & 1.02 \\
\hline MRI 7 & $\mathrm{~S}$ & 2.42 & 3.63 & 1.05 & 1.24 \\
\hline MRI DK 1 & $\mathrm{~S}$ & 3.43 & 3.77 & 1.78 & 2.36 \\
\hline MRI DK 2 & $\mathrm{~S}$ & 2.51 & 3.40 & 2.72 & 6.49 \\
\hline MRI DK 3 & S & 1.70 & 2.46 & 1.38 & 2.36 \\
\hline 15HRWYT/07-224 & $\mathrm{S}$ & 2.08 & 2.99 & 1.67 & 2.06 \\
\hline Pobeda & $\mathrm{S}$ & 3.23 & 4.56 & 1.60 & 2.02 \\
\hline Renesansa & $\mathrm{S}$ & 2.21 & 2.57 & 1.37 & 1.33 \\
\hline Zemunska rosa 1 & $\mathrm{~S}$ & 3.54 & 5.81 & 2.83 & 3.30 \\
\hline Apache & $\mathrm{S}$ & 3.02 & 4.17 & 2.31 & 2.70 \\
\hline Zemunska rosa 2 & $\mathrm{~S}$ & 2.88 & 4.05 & 2.60 & 3.32 \\
\hline MRI AU 15 & $\mathrm{~S}$ & 2.99 & 3.57 & 2.50 & 3.27 \\
\hline ZP Olga & $\mathrm{S}$ & 2.19 & 3.99 & 1.59 & 3.69 \\
\hline MRI 146 & $\mathrm{~S}$ & 2.45 & 5.11 & 2.59 & 6.21 \\
\hline MRI 162 & $\mathrm{~S}$ & 2.08 & 3.82 & 1.88 & 2.54 \\
\hline MRI 165 & $\mathrm{~S}$ & 1.74 & 2.99 & 1.55 & 2.65 \\
\hline MRI S3/I & $\mathrm{F}$ & 2.89 & 7.05 & 2.23 & 3.88 \\
\hline MRI S4/I & $\mathrm{F}$ & 2.50 & 6.08 & 1.58 & 2.35 \\
\hline MRI S7/I & $\mathrm{F}$ & 1.52 & 4.10 & 1.91 & 2.54 \\
\hline MRI S10/I & $\mathrm{F}$ & 2.49 & 6.45 & 2.45 & 4.56 \\
\hline MRI 10/II & $\mathrm{F}$ & 2.40 & 5.26 & 2.49 & 3.31 \\
\hline MRI S11/I & $\mathrm{F}$ & 1.65 & 2.91 & 1.43 & 2.45 \\
\hline MRI S12/I & $\mathrm{F}$ & 1.65 & 3.77 & 1.31 & 1.96 \\
\hline MRI S134/I & $\mathrm{F}$ & 1.76 & 2.54 & 2.08 & 3.17 \\
\hline MRI S134/II & $\mathrm{F}$ & 2.40 & 4.42 & 2.37 & 3.76 \\
\hline MRI S268/I & $\mathrm{F}$ & 2.48 & 4.41 & 1.56 & 2.89 \\
\hline MRI D1/I & $\mathrm{F}$ & 2.64 & 3.04 & 2.03 & 2.39 \\
\hline MRI D3/I & $\mathrm{F}$ & 1.91 & 2.23 & 1.71 & 2.48 \\
\hline MRI D6/I & $\mathrm{F}$ & 2.31 & 3.09 & 1.44 & 2.03 \\
\hline MRI D10/I & $\mathrm{F}$ & 2.46 & 3.13 & 1.91 & 2.77 \\
\hline MRI D10/II & $\mathrm{F}$ & 1.69 & 2.64 & 1.49 & 2.51 \\
\hline MRI D11/II & $\mathrm{F}$ & 2.06 & 4.08 & 1.64 & 2.56 \\
\hline MRI D12/I & $\mathrm{F}$ & 1.73 & 3.36 & 1.34 & 1.71 \\
\hline MRI D14/I & $\mathrm{F}$ & 2.01 & 3.80 & 1.45 & 2.48 \\
\hline MRI D16/I & $\mathrm{F}$ & 2.43 & 5.98 & 2.60 & 4.20 \\
\hline MRI D18/II & $\mathrm{F}$ & 1.74 & 3.10 & 1.55 & 2.85 \\
\hline MRI D19/I & $\mathrm{F}$ & 2.43 & 3.85 & 2.27 & 3.37 \\
\hline MRI D20/IP & $\mathrm{F}$ & 2.56 & 3.91 & 2.15 & 3.70 \\
\hline MRI D20/IH & $\mathrm{F}$ & 1.77 & 2.90 & 1.42 & 1.93 \\
\hline MRI D21/I & $\mathrm{F}$ & 2.15 & 4.40 & 1.58 & 3.90 \\
\hline MRI D22/I & $\mathrm{F}$ & 1.85 & 3.28 & 2.35 & 4.64 \\
\hline MRI D25I & $\mathrm{F}$ & 2.49 & 4.98 & 2.87 & 4.74 \\
\hline MRI D28/1 & $\mathrm{F}$ & 2.30 & 4.75 & 2.56 & 4.54 \\
\hline Means & & 2.31 & 3.94 & 1.91 & 3.03 \\
\hline Standard deviation & & 0.50 & 1.13 & 0.51 & 1.16 \\
\hline CV $(\%)$ & & 21.87 & 28.82 & 26.85 & 38.34 \\
\hline Standard error & & 0.07 & 0.17 & 0.08 & 0.18 \\
\hline \multirow{3}{*}{$\mathrm{LSD}_{0.05}$} & Year $(\mathrm{Y})$ & 0.01 & 0.02 & 0.01 & 0.02 \\
\hline & \multirow{2}{*}{$\begin{array}{c}\text { Genotype }(\mathrm{G}) \\
\text { Interaction } \mathrm{Y} \times \mathrm{G}\end{array}$} & 0.05 & 0.09 & 0.05 & 0.09 \\
\hline & & 0.08 & 0.13 & 0.08 & 0.13 \\
\hline
\end{tabular}

$\overline{1}$ - expressed as mg WSC $100 \mathrm{mg}^{-1}$ dry weight, ${ }^{2}$ - expressed as $\mathrm{mg} \mathrm{cm}{ }^{-1}$ WSC length; genotype group: $\mathrm{S}$ - standard, $\mathrm{F}-\mathrm{F}_{4: 5}$ - families

Table 2. Total sum of squares from analysis of variance and heritability for the water-soluble carbohydrates (WSC) related traits for the 44 wheat genotypes grown in two years

\begin{tabular}{ccccc}
\hline Traits & Genotype $(\mathrm{G})$ & Year $(\mathrm{Y})$ & Interaction $\mathrm{G} \times \mathrm{Y}$ & \multicolumn{2}{c}{ Heritability } \\
(degree of freedom) & 43 & 1 & 43 & $\%$ \\
\hline WSC content, mg $100 \mathrm{mg}^{-1}$ dry weight & $51^{*}$ & $11^{*}$ & $16^{*}$ & 68.0 \\
WSCSC content, $\mathrm{mg} \mathrm{cm}^{-1}$ length & $250^{*}$ & $54^{*}$ & $92^{*}$ & 63.1 \\
\hline
\end{tabular}

* - significant at the 0.01 level of probability 
Table 3. Results of random forest analysis for predictions of the importance of 16 morphological (normal font) and anatomical traits (bold font) for water-soluble carbohydrates (WSC) content and water-soluble carbohydrates specific content (WSCSC) based on 44 wheat genotypes

\begin{tabular}{|c|c|c|c|c|c|c|c|}
\hline \multicolumn{4}{|c|}{$\mathrm{WSC}^{1}$} & \multicolumn{4}{|c|}{$\mathrm{WSSC}^{1}$} \\
\hline \multicolumn{2}{|c|}{2011} & \multicolumn{2}{|c|}{2012} & \multicolumn{2}{|c|}{2011} & \multicolumn{2}{|c|}{2012} \\
\hline trait $^{1}$ & $\%$ & trait & $\%$ & trait & $\%$ & trait & $\%$ \\
\hline $\mathrm{ACH}$ & 18.39 & FLA & 12.17 & BMS & 12.77 & CHL & 12.28 \\
\hline API & 12.80 & PDE & 10.49 & PA & 11.91 & BMS & 12.12 \\
\hline CHL & 9.84 & CHL & 8.92 & CHL & 10.80 & PA & 9.06 \\
\hline FLA & 8.76 & API & 8.50 & SWT & 8.59 & $\mathrm{SH}$ & 8.93 \\
\hline BMS & 8.48 & PDS & 7.15 & LTS & 7.00 & PDS & 8.58 \\
\hline PDE & 7.66 & PDL & 6.97 & ACH & 6.29 & SWT & 7.35 \\
\hline DTF & 6.30 & BMS & 6.53 & DTF & 6.14 & PDL & 5.41 \\
\hline LTS & 4.51 & DTF & 5.98 & TDR & 5.91 & DTF & 5.20 \\
\hline PASS & 4.06 & ACH & 5.73 & PASS & 5.42 & LTS & 4.72 \\
\hline PDS & 3.97 & $\mathrm{SH}$ & 5.45 & PDE & 5.40 & FLA & 4.68 \\
\hline TDR & 2.97 & PASS & 5.00 & FLA & 4.69 & PASS & 4.40 \\
\hline PDL & 2.78 & PA & 4.06 & SH & 3.98 & ACH & 4.35 \\
\hline BBN & 2.72 & SWT & 3.76 & BBN & 3.39 & PDE & 4.30 \\
\hline $\mathrm{SH}$ & 2.47 & LTS & 3.67 & PDS & 2.93 & BBN & 4.10 \\
\hline SWT & 2.31 & TDR & 3.48 & API & 2.81 & TDR & 2.28 \\
\hline PA & 1.98 & BBN & 2.17 & PDL & 1.99 & API & 2.23 \\
\hline
\end{tabular}

${ }^{1}$ - data recorded at 10 days after anthesis (before stress was imposed); codes: ACH - area of chlorenchyma, API - area of pith intercellular, BBN - bigger bundles in parenchyma, BMS - biomass per main stem, CHL - chlorophyll content, DTA - days to anthesis, FLA - flag leaf area, LTS - lignified tissue share, PA - area of parenchyma, PASS - total phloem area/stem section, PDE - peduncle extrusion, PDL - peduncle length, PDS - peduncle share, SH - stem height, SWT - stem wall thickness, TDR - total phloem area/stem section

Table 4. Comparison of selected groups of wheat genotypes with high and low water-soluble carbohydrates specific content (WSCSC)

\begin{tabular}{|c|c|c|c|c|c|c|}
\hline \multirow[b]{2}{*}{ Trait } & \multicolumn{2}{|c|}{2011} & \multirow[b]{2}{*}{$t$-test } & \multicolumn{2}{|c|}{2012} & \multirow[b]{2}{*}{$t$-test } \\
\hline & $\begin{array}{c}\text { high } \\
\text { WSCSC }\end{array}$ & $\begin{array}{c}\text { low } \\
\text { WSCSC }\end{array}$ & & $\begin{array}{c}\text { high } \\
\text { WSCSC }\end{array}$ & $\begin{array}{c}\text { low } \\
\text { WSCSC }\end{array}$ & \\
\hline WSCSC content, $\mathrm{mg} \mathrm{cm}^{-1}$ & 5.6 & 2.67 & $* * *$ & 4.69 & 1.77 & $* * *$ \\
\hline WSC content, mg $100 \mathrm{mg}^{-1} \mathrm{DW}$ & 2.67 & 1.83 & $* * *$ & 2.44 & 1.37 & $* * *$ \\
\hline Days to anthesis (from $1^{\text {st }}$ January) & 139.60 & 138.70 & ns & 140.00 & 137.20 & ns \\
\hline Chlorophyll content (SPAD units) & 51.26 & 48.51 & ns & 56.01 & 53.08 & ns \\
\hline Flag leaf area $\mathrm{cm}^{2}$ & 27.52 & 24.92 & ns & 38.13 & 33.67 & $*$ \\
\hline Stem height $\mathrm{cm}$ & 69.20 & 74.33 & ns & 59.23 & 63.59 & ns \\
\hline Peduncle length $\mathrm{cm}$ & 31.96 & 32.75 & ns & 32.40 & 32.14 & ns \\
\hline Peduncle share $\%$ & 46.51 & 42.50 & $*$ & 55.20 & 50.54 & $*$ \\
\hline Peduncle extrusion $\mathrm{cm}$ & 12.76 & 13.98 & ns & 16.72 & 15.07 & ns \\
\hline Stem specific weight $\mathrm{mg} \mathrm{cm}^{-1}$ & 45.56 & 34.65 & $* * *$ & 35.04 & 25.46 & $* * *$ \\
\hline Biomass/main stem $g$ & 4.47 & 3.57 & $* * *$ & 3.01 & 2.29 & $* * *$ \\
\hline Stem wall thickness mm & 0.60 & 0.51 & * & 0.58 & 0.51 & $*$ \\
\hline Total vascular bundles in parenchyma, No. & 61.76 & 55.26 & ns & 54.60 & 47.50 & $* *$ \\
\hline Area of chlorenchyma $\mathrm{mm}^{2}$ & 0.65 & 0.59 & ns & 0.60 & 0.49 & $*$ \\
\hline Area of parenchyma mm² & 2.50 & 1.88 & $*$ & 2.39 & 1.90 & $*$ \\
\hline Stem wall thickness/stem diameter ratio \% & 19.50 & 17.62 & ns & 18.85 & 18.91 & ns \\
\hline Area of pith intercelular $\mathrm{mm}^{2}$ & 3.16 & 2.96 & ns & 3.13 & 2.43 & ns \\
\hline Total phloem area/stem section $\mathrm{mm}^{2}$ & 0.05 & 0.04 & $*$ & 0.06 & 0.05 & $* *$ \\
\hline Lignified tissue share $\%$ & 32.00 & 35.70 & ns & 33.03 & 32.78 & ns \\
\hline Grain weight/main spike $g$ & 2.91 & 2.69 & ns & 1.61 & 1.47 & ns \\
\hline Harvest index \% & 47.58 & 49.84 & ns & 37.69 & 40.34 & ns \\
\hline Grains/spike, No. & 57.90 & 54.62 & ns & 35.56 & 33.10 & ns \\
\hline Thousand grain weight $g$ & 50.30 & 49.64 & ns & 44.93 & 44.83 & ns \\
\hline
\end{tabular}

Note. Groups of ten wheat genotypes with high WSCSC and ten wheat genotypes with low WSCSC were compared; significance indicated: ${ }^{* * *}-P=0.001,{ }^{*}-P=0.01,{ }^{*}-P=0.05$, ns - not significant; all values are from control plants. 

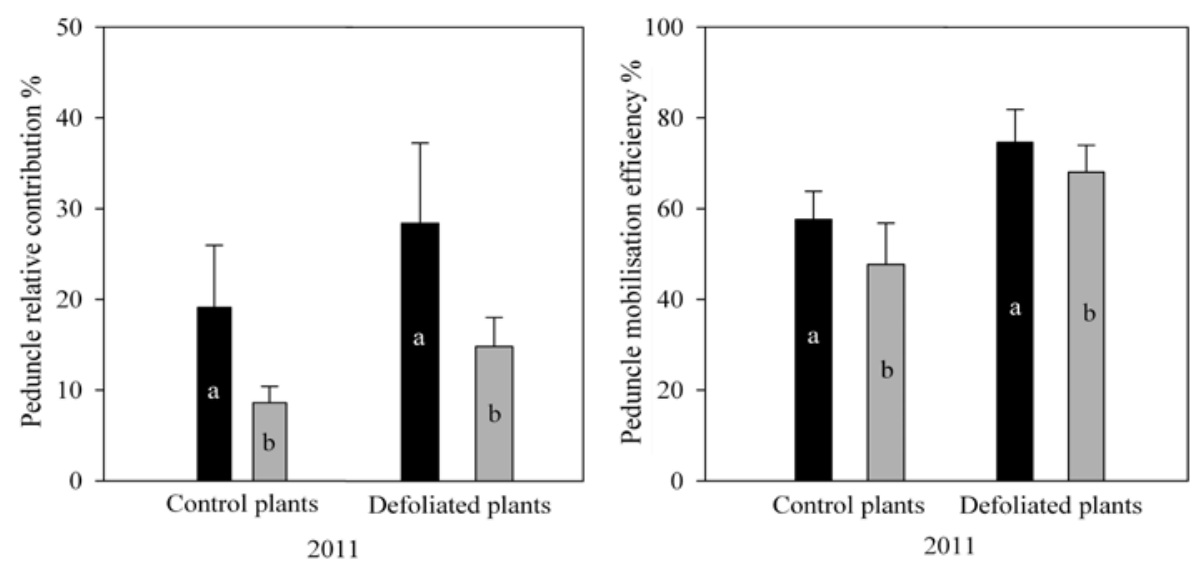

Notes. Values are means for ten wheat genotypes with the highest and the lowest water soluble carbohydrate specific content (WSCSC). Error bars represent standard deviation. Means of high- and low-WSCSC within same trait and same treatment followed by the same letter are not significantly different $(P<0.05)$. Letters correspond to ranking of groups after $t$-test.

Figure 2. Estimated relative contribution of peduncle reserves to grain weight and peduncle mobilization efficiency from peduncle with high- (black boxes) and low-water soluble carbohydrate specific content (grey boxes) in control and defoliated plants in 2011

(28.4\% vs $14.8 \%$, respectively). Significantly higher efficiency in the WSC translocation $(P<0.05)$ was also found in high-WSCSC than in low-WSCSC in both control $(57.6 \%$ vs $47.7 \%$, respectively) and defoliated (74.6\% vs $68.0 \%$, respectively) plants.

\section{Discussion}

In the present study we used defoliation treatment shortly after anthesis to simulate a terminal drought stress by inhibiting current assimilation. Average grain weight reduction across 44 genotypes and two years due to leaf blades removal was 19\% (Dodig et al., 2016), which agrees well with results of the wheat experiments in field conditions under natural terminal drought (Amiri et al., 2013; Dias de Oliveira et al., 2015).

Although experimental conditions were designed to be the same in both years, temperature and/or rainfall pattern differences during the spring vegetative period were probably the reason for higher peduncle reserves accumulation in 2011. Accumulation of water-soluble carbohydrates usually occurs between anthesis and the completion of endosperm cell division (Slewinski, 2012). This period, which in our case occurred in May and June, was on average similar in both years by temperature, but rainfall and sunshine hours were higher in 2011 than in 2012 (Dodig et al., 2016). High environmental effects on WSC at athensis were reported also in other studies (Shearman et al., 2005; Ruuska et al., 2006).

The significant genotype $\times$ year interaction for WSC and WSCSC was mainly due to differences in changes of magnitudes rather than in ranking of genotypes in different years. Several previous studies in wheat have also shown that the predominant source of variation for WSC was a genotype (Ruuska et al., 2006; Saint Pierre et al., 2010). The moderate broadsense heritability values observed in this study for both WSC and WSCSC (63\% and $68 \%$, respectively) can be explained by a relatively high magnitude of the genotype $\times$ year interaction. In previous studies on wheat, broadsense heritability of stem WSC at the flowering stage and 10 days after anthesis was estimated to be $49-51 \%$ and
$32 \%$, respectively (Yang et al., 2007; Saint Pierre et al., 2010). Rebetzke et al. (2008) described WSC as being constitutive with moderate to relatively high narrow sense heritabilities (51-77\%) within environments. On the other hand, trials with a diverse group of genotypes grown across multiple environments in Australia showed a very high genotypic component for WSC (heritability was over $90 \%$ based on entry mean) and a relatively small interaction with environment, strongly supporting the view that breeding for high WSC may be possible (Ruuska et al., 2006). Genotypes ranked more consistently across years for WSCSC $\left(r_{s}=0.82\right)$ than for WSC $\left(r_{s}=0.59\right)$ by Spearman rank correlation coefficient $\left(r_{s}\right)$, suggest that WSCSC is more reliable for breeding.

Not a single trait showed particularly high or distinct influence from other traits on WSC or WSCSC. However, several traits such as area of pith intercellular (API), chlorophyll content (CHL) and flag leaf area (FLA) showed to be among the most important traits for WSC in both years. Area of chlorenchyma (ACH) was far the most important for WSC in the first year, but in the second year its impact on WSC was not high. The opposite was true for peduncle extrusion (PDE). Biomass per main stem (BMS), area of parenchyma (PA) and CHL were the most important traits for WSCSC in both seasons. Thus, CHL appeared to be amongst the most influential traits for both WSC and WSCSC. The chlorophyll content has been reported to be positively correlated with the photosynthetic rate (Thomas et al., 2005). In general, morphology of the plants showed to be a slightly better predictor for WSC-related traits than the peduncle anatomy.

In both years, high-WSCSC genotypes had a significantly greater $(P<0.001)$ specific weight and biomass of the main stem (both based on dry weight) than genotypes with low WSCSC. Biomass per plant is a very important selection criterion for developing genotypes with high yield and terminal water stress tolerance (Dodig et al., 2008). Ehdaie et al. (2006 a) reported that high internode specific weight and balanced partitioning of stem length into lower and upper internodes are important in genotypic accumulation and mobilisation of stem 
reserves in wheat. Among three peduncle morphology related traits (peduncle length, peduncle extrusion and peduncle share in total stem length) that were examined, only the latter significantly differed $(P<0.05)$ between the two groups (in favour of high-WSCSC group). Although high-WSCSC genotypes tend to be earlier and have a shorter stem as well as higher $\mathrm{CHL}$ and larger FLA, these traits did not differ significantly between the two groups. The only exception was FLA in the second (more stressed) year when significantly $(P<0.05)$ larger flag leaves were associated with high-WSCSC genotypes. Our findings correspond well with results of other authors (Ehdaie et al., 2006 b; Ruuska et al., 2006) that differences in WSC accumulation were not significantly associated with days to flowering and stem height.

In contrast to morphology, associations of anatomy traits with WSC accumulation in wheat have been much less investigated. Regarding high- and lowWSCSC genotype groups, stem wall thickness (SWT), PA and phloem area (PAP) were the only anatomical traits significantly different for the two groups of genotypes in both years. The opposite is true for total phloem area/ stem section (TDR), lignified tissue share (LTS) and API. Dreccer et al. (2013) reported that wheat recombinant inbred lines with a high WSC concentration had a larger wall area when compared with low WSC concentration ones. Saint Pierre et al. (2010) suggested that under same biomass production per area, solid stems would have more WSC available for translocation to the grains, resulting in higher yields. Expected benefits would be greater under water stress conditions. However, it is not only storage capacity that is important for filling of developing grains under water stress conditions but also transport capacity of carbon from the source (stem) to the sink (grain). In our study high-WSCSC genotypes had also a significantly higher PAP than low-WSCSC genotypes, suggesting that there is probably a close relationship between capacity of an organ to translocate accumulated dry matter and the amount of phloem it contains. In the second year, highWSCSC genotypes had also a significantly higher number of vascular bundles in parenchyma and significantly more area of clorenchyma $(\mathrm{ACH})$.

Although several morphological and anatomical traits were significantly higher in high- than in low-WSCSC genotypes, grain weight/main spike (GWS) was not significantly improved in former, both in control and desiccated plants. However, one can still notice a higher grain weight of about $5 \%$ and $10 \%$ in high-WSCSC genotypes compared to low ones in control and defoliated plants, respectively, under mild stress conditions (first season). In the second season, the average grain weight was lower for $47 \%$ and $53 \%$ in control and defoliated plants, respectively, compared with the first season. Under such more stress conditions high-WSCSC genotypes had no grain weight advantage compared to low-WSC (1.46 vs 1.48, respectively) in control plants, while in defoliated plants there was $13 \%$ difference in favour of high-WSCSC (1.15 vs 1.00). Also, GWS reduction due to the defoliation treatment in high-WSSC genotypes was lower in comparison to low-WSCSC by $4 \%(15 \%$ vs $19 \%)$ and by $11 \%(22 \%$ vs $33 \%$ ) in the first and the second season, respectively.
This suggests that the relative advantage of high-WSCSC genotypes for grain weight was greater in defoliated plants than in controlled plants. Ruuska et al. (2006) also found no significant difference in grain yield between low and high WSC genotypes in set of 22 genotypes grown in six representative environments of the wheat-growing region of south-eastern Australia. These authors concluded that breeding for high WSC accumulation should be possible, since heritability of the trait is high, but selection of useful high WSC breeding material remains problematic.

It is not only storage capacity important for filling of developing grains, but also larger efficiency in the WSC translocation. In the study performed by Wang et al. (2001) it was reported that photosynthesis in the exposed peduncle and flag leaf sheath contributed to about $9-12 \%$ of grain dry mass, depending on the wheat cultivar. In our study, high-WSCSC genotypes had significantly higher contribution $(P<0.001)$ to GWS in control plants from peduncle than low-WSCSC genotypes for one-fold. The similar one-fold higher contribution $(P<0.001)$ to GWS from peduncle in high-WSCSC genotypes than in lowWSCSC genotypes was estimated for defoliated plants. Significantly higher efficiency in the WSC translocation $(P<0.05)$ was also found in high-WSCSC than in lowWSCSC in both control and defoliated plants. This is in accordance with previous studies showing that reserves from peduncle (Ehdaie et al., $2006 \mathrm{~b}$ ) or from the whole stem (Foulkes et al., 2007) had a greater contribution to grain yield and mobilisation efficiency under water stress than under non-stress conditions. However, as in the case of WSC and WSCSC, there was no significant correlation between grain weight per spike and estimated contribution of mobilized peduncle reserves to grain weight or peduncle mobilization efficiency (data not shown). It is argued that the capacity for maintaining large storage in stems may be linked to carbohydrate partitioning during the development of stem characteristics. If greater partitioning to the stem is at the basis of high reserve storage then it might perhaps be at the expense of grain yield potential (Blum, 1998). Also, differences in tillering can result in higher biomass accumulation in stem than in leaves (Dreccer et al., 2009). A low tillering and high WSC accumulation genotypes found to be superior in performance under terminal drought compared to high tillering and low WSC genotypes (Dreccer et al., 2013). Hence, in the context of breeding, it is important to determine what disadvantages may affect yield or its components during selection for high stem WSC concentration.

\section{Conclusion}

High-water-soluble carbohydrates specific (WSCSC) genotypes had higher share of peduncle in total stem length, higher specific weight and biomass of the main stem, as well as larger parenchyma and phloem area compared to low-WSCSC genotypes. In more severe stress conditions, flag leaf area, numbers of vascular bundles in parenchyma and assimilation tissues were also significantly higher in high- than in low-WSCSC genotypes. Furthermore, high-WSCSC genotypes showed higher contribution of water-soluble carbohydrates (WSC) from peduncle to spike grain 
weight and its mobilisation efficiency than low-WSCSC genotypes, both in control and defoliated plants. These differences probably resulted in higher grain weight per spike of high-WSCSC genotypes in comparison with low-WSCSC genotypes, particularly under stress, but this increase was not significant. This suggests that simple breeding for high water-soluble concentration in peduncle would not give clear advantage in final yield, even under stress conditions. Other mechanisms such as the proportion of leaf $v s$ stem biomass or source-sink status should also be taken into account.

\section{Acknowledgements}

This work was supported by the Serbian Ministry of Education, Science and Technological Development under Grant TR 31005 and by the EU FP7 project, Grant Agreement No. 316004 (REGPOT-AREA).

Received 09112016 Accepted 02032017

\section{References}

Amiri R., Bahraminejad S., Jalali-Honormand S. 2013. Effect of terminal drought stress on grain yield and some morphological traits in 80 bread wheat genotypes. International Journal of Agriculture and Crop Sciences, 5 (10): $1145-1153$

Blum A. 1998. Improving wheat grain filling under stress by stem reserve mobilization. Euphytica. 100 (1): 77-83 https://doi.org/10.1023/A:1018303922482

Chaves M., Davies B. 2010. Drought effects and water use efficiency: improving crop production in dry environments. Functional Plant Biologv. 37: 3-6 https://doi.org/10.1071/FPv37n2 FO

Dias de Oliveira E., Palta J. A., Bramley H., Stefanova K., Siddique K. H. M. 2015. Elevated $\mathrm{CO}_{2}$ reduced floret death in wheat under warmer average temperatures and terminal drought. Frontiers in Plant Science. 6: 1010 https://doi.org/10.3389/fpls.2015.01010

Dodig D., Zorić M., Knežević D., King S. R., SurlanMomirović G. 2008. Genotype × environment interaction for wheat yield in different drought stress conditions and agronomic traits suitable for selection. Australian Journal of Agricultural Research. 59 (6): 536-545 https://doi.org/10.1071/AR07281

Dodig D., Savić J., Kandić V., Zorić M., Vucelić Radović B. Popović A., Quarrie S. 2016. Responses of wheat plants under post-anthesis stress induced by defoliation. I. Contribution of agro-physiological traits to grain yield. Experimental Agriculture. 52 (2): 203-223 https://doi.org/10.1017/S0014479715000034

Dreccer M. F., van Herwaarden A. F., Chapman S. C. 2009. Grain number and grain weight in wheat lines contrasting for stem water soluble carbohydrate concentration. Field Crops Research. 112 (1): 43-54 https://doi.org/10.1016/j.fcr.2009.02.006

Dreccer M. F., Chapman S. C., Rattey A. R., Neal J., Song Y., Christopher J. T., Reynolds M. 2013. Developmental and growth controls of tillering and water-soluble carbohydrate accumulation in contrasting wheat (Triticum aestivum L.) genotypes: can we dissect them? Journal of Experimental Botany. 64 (1): 143-160 https://doi.org/10.1093/jxb/ers317

Ehdaie B., Alloush G. A., Madore M. A., Waines J. G. 2006 (a) Genotypic variation for stem reserves and mobilization in wheat. I. Post anthesis changes in internode dry matter. Crop Science. 46 (2): 735-746 https://doi.org/10.2135/cropsci2005.04-0033
Ehdaie B., Alloush G. A., Madore M. A., Waines J. G. 2006 (b). Genotypic variation for stem reserves and mobilization in wheat. II. Postanthesis changes in internode water-soluble carbohydrates. Crop Science. 46 (2): 2093-2103 https://doi.org/10.2135/cropsci2006.01.0013

Ehdaie B., Alloush G. A., Waines J. G. 2008. Genotypic variation in linear rate of grain growth and contribution of stem reserves to grain yield in wheat. Field Crops Research. 106 (1): 34-43 https://doi.org/10.1016/j.fcr.2007.10.012

Foulkes M. J., Sylvester-Bradley R., Weightman R., Snape J. W. 2007. Identifying physiological traits associated with improved drought resistance in winter wheat. Field Crops Research. 103 (1): 11-24 https://doi.org/10.1016/j.fcr.2007.04.007

Genuer R., Poggi J.-M., Tuleau-Malot C. 2010. Variable selection using random forests. Pattern Recognition Letters. 31 (14): 2225-2236 https://doi.org/10.1016/j.patrec.2010.03.014

Hallauer A. R., Carena M. J., Miranda Filho J. B. 2010 Quantitative genetics in maize breeding. New York, USA

Kong L., Wang F., Feng B., Li S., Si J., Zhang B. 2010. The structural and photosynthetic characteristics of the exposed peduncle of wheat (Triticum aestivum L.): an important photosynthate source for grain-filling. BMC Plant Biology, 10: 141

https://doi.org/10.1186/1471-2229-10-141

Li P., Chen J., Wu P. 2011. Agronomic characteristics and grain yield of 30 spring wheat genotypes under drought stress and nonstress conditions. Agronomy Journal, 103 (6): 1619-1628 https://doi.org/10.2134/agronj2011.0013

Nawaz A., Farooq M., Cheema S. A., Wahid A. 2013. Differential response of wheat cultivars to terminal heat stress. International Journal of Agricultural and Biology, 15 (6): 1354-1358

Prasad P., Pisipati S., Mutava R., Tuinstra M. 2008. Sensitivity of grain sorghum to high temperature stress during reproductive development. Crop Science, 48 (5): 1911-1917 https://doi.org/10.2135/cropsci2008.01.0036

Rebetzke G. J., van Herwaarden A. F., Jenkins C., Weiss M., Lewis D., Ruuska S., Tabe L., Fettel N., Richards R. A. 2008. Quantitative trait loci for water soluble carbohydrates and associations with agronomic traits in wheat. Australian Journal of Agricultural Research, 59 (10): 891-905 https://doi.org/10.1071/AR08067

RuuskaS.A., RebetzkeG. J., vanHerwaardenA.F., Richards R. A., Fettell N. A., Tabe L., Jenkins C. L. D. 2006. Genotypic variation in water-soluble carbohydrate accumulation in wheat. Functional Plant Biologv. 33 (9): 799-809 https://doi.org/10.1071/FP06062

Saint Pierre C., Trethowan R. M., Reynolds M. 2010. Stem solidness and its relationship to water-soluble carbohydrates: association with wheat yield under water deficit. Functional Plant Biology, 37 (2): 166-174 https://doi.org/10.1071/FP09174

Scofield G. N., Ruuska S. A., Aoki N., Lewis D. S., Tabe L. M., Jenkins C. L. D. 2009. Starch storage in the stems of wheat plants: localization and temporal changes. Annals of Botany, 103 (6): 859-868 https://doi.org/10.1093/aob/mcp010

Shearman V. J., Sylvester-Bradley R., Scott R. K., Foulkes M. J. 2005. Physiological processes associated with wheat yield progress in the UK. Crop Science, 45 (1): 175-185

Slewinski T. L. 2012. Non-structural carbohydrate partitioning in grass stems: a target to increase yield stability, stress tolerance, and biofuel production. Journal of Experimental Botany, 63 (13): 4647-4670 https://doi.org/10.1093/jxb/ers124

Thomas J. A., Jeffrey A. C., Atsuko K., David M. K. 2005. Regulating the proton budget of higher plant photosynthesis. Proceedings of the National Academy of Sciences USA, 102 (27): 9709-9713 https://doi.org/10.1073/pnas.0503952102 
Villegas D., García del Moral L. F., Rharrabti Y., Martos V., Royo C. 2007. Morphological traits above the flag leaf node as indicators of drought susceptibility index in durum wheat. Journal of Agronomy and Crop Science, 193 (2): 103-116

https://doi.org/10.1111/j.1439-037X.2006.00246.x

Wang Z. M., Wei A., Zheng D. M. 2001. Photosynthetic characteristics of non-leaf organs of winter wheat cultivars differing in ear type and their relationship with grain mass per ear. Photosynthetica, 39 (2): 239-244

https://doi.org/10.1023/A:1013743523029
Yang D. L., Jing R. L., Chang X. P., Li W. 2007. Identification of quantitative trait loci and environmental interactions for accumulation and remobilization of water-soluble carbohydrates in wheat. Genetics, 176 (1): 571-584 https://doi.org/10.1534/genetics.106.068361

\title{
Vandenyje tirpių angliavandenių kaupimasis kviečio žiedynkotyje ir jų ryšys su morfoanatominiais bei produktyvumo požymiais
}

\author{
A. Šešlija ${ }^{1}$, B. Vucelić-Radović ${ }^{1}$, S. Stanojević1 ${ }^{1}$ J. Savić1 ${ }^{1}$ D. Rančić1 ${ }^{1}$ I. Pećinar ${ }^{1}$, \\ V. Kandić2, D. Dodig² \\ ${ }^{1}$ Belgrado universitetas, Serbija \\ ${ }^{2}$ Serbijos kukurūzų tyrimų institutas
}

\section{Santrauka}

Kviečių stiebų tarpubambliuose besikaupiantys vandenyje tirpūs angliavandeniai gali reikšmingai prisidèti prie grūdų pildymosi, ypač streso sąlygomis. Dvejų metų lauko eksperimente 44 genotipų kviečiuose nustatyta vandenyje tirpių ir genotipui specifinių vandenyje tirpių angliavandenių kiekiai pagrindinio stiebo aukščiausiame tarpubamblyje (žiedynkotyje) 10 dienų po žydèjimo. Defoliacija atlikta po žydejjimo praèjus 10 dienų nupjaunant visus lapus. Defoliuoti augalai auginti kartu su sveikais kontroliniais augalais. Iš 16 morfologinių, anatominiu ir vystymosi požymių vandenyje tirpių angliavandenių kaupimuisi žiedynkotyje svarbiausi buvo žiedynkočio parenchimos tarpląstelinè sritis, chlorofilo kiekis viršutiniame lape ir šio lapo plotas. Nustatyta tendencija, kad didesnị skaičių grūdų varpoje turejjo ir defoliuotų, ir kontrolinių augalų genotipai su dideliu kiekiu specifinių vandenyje tirpių angliavandenių nei genotipai su mažu šių angliavandenių kiekiu.

Reikšminiai žodžiai: defoliacija, fruktanas, genotipas, grūdų svoris, Triticum aestivum. 